\title{
Patient Safety Related Implementations of Nurses Working in the Neonatal Intensive Care Unit and Related Factors
}

\author{
(1) Elanur Kaleci', (1) Fatma Taş Arslan² \\ ${ }^{1}$ Necmettin Erbakan University Faculty of Nursing, Department of Pediatric Nursing, Konya, Turkey \\ ${ }^{2}$ Selçuk University Faculty of Nursing, Department of Pediatric Nursing, Konya, Turkey
}

\begin{abstract}
Aim: This study was carried out in order to determine patient safety related implementations of nurses working in neonatal intensive care.

Materials and Methods: This descriptive study was carried out in Neonatal Intensive Care Units (NICU) in six hospitals in Konya city center between April and May 2012. Ninety-six nurses working in intensive care units participated in this survey. Newborn Patient Safety Survey Form was used in this study. The analysis of the data was done by number, percentage, Kruskall-Wallis, Man-Whitney $\mathrm{U}$ and Independent $\mathrm{t}$ tests.

Results: It was seen that nurses scored most in interventions regarding falling among the fields of patient safety implementations ( $92.42 \pm 6.36$ ). A meaningful difference was found between NICU nurses' state of education and patient safety intervention regarding the medication score average $(p<0.05)$ and also nurses' working years and patient safety intervention regarding identity implementations score average $(p<0.05)$.

Conclusion: It was determined that nurses implemented interventions regarding falling most among patient safety implementations. It was seen that patient safety implementations of nurses were related to their state of education, working years, the number of patients cared for daily, and also receiving patient safety training.
\end{abstract}

Keywords: Nurses, patient safety, intensive care units, neonatal

\section{Introduction}

Patient safety is all of the precautions taken by the health institutions and personnel of these institutions in order to pre-determine, report and correct errors and prevent injury caused by health care services $(1,2)$. The aim of patient safety is to provide safety by creating an environment which will affect patients, patients' relatives and hospital personnel psychologically and physically. Patient safety is a basic need and an unmistakable right of individuals (2).

Neonatal intensive care units (NICU) are special, multidisciplinary units constructed to provide care for patients who need special care and whose health condition is critical $(3,4,5,6,7,8)$. The fact that the newborn in NICU is vulnerable to external factors increases the risk of medical error. Medical errors occur in premature babies especially in the ones born before the $30^{\text {th }}$ week of pregnancy and those lighter than 1.500 grams (57\% in 24 to 27 -week-babies whereas only $3 \%$ in full-term babies) (9).

Neonatal nurses are important in providing and continuing patient safety and for their efficiency in carrying out activities during the patient's stay in hospital. Nurses are intertwined with patient safety in every field of care. 
Informing on medical error, decreasing or removing the risk of medical error, supporting patient safety and reporting unwanted events are among the duties of nurses. Nurses who work in units such as NICU which require sensitivity about patient safety should take an active role and be careful (10).

Recently some implementations regarding prevention and control of infections, color code implementations, safety reporting systems, training health personnel in patient and personnel safety and setting up committees in order to carry out the necessary activities to provide patient and employee safety have been performed in our country (11). However, in the literature, a limited number of studies regarding patient safety of nurses working in pediatric clinics have been reported in our country $(12,13)$. Also, no studies about patient safety in NICU are to be found in our country. It is necessary to carry out studies to raise nurses' awareness of patient safety and to determine the inadequacies in patient safety in NICU and nursing implementations. These studies will contribute to determine nursing implementations related to patient safety and to remove inadequacies in safety implementations for patients who receive care. Furthermore, it is thought that they will contribute to increase the importance given to patient safety as well as to take precautions to provide and improve patient safety. In this context, this study was carried out to find out about nursing implementations of NICU nurses regarding patient safety and related factors.

\section{Research questions:}

- What is the intervention score of nurses working in NICU regarding patient safety implementations?

- What are the factors related to nursing intervention scores of patient safety implementations?

\section{Materials and Methods}

This study was carried out in NICUs of six hospitals in Konya city center in 2012 descriptively. In this research, 101 nurses were included in the sample without any participation criteria as the number of nurses in the population was limited. However, 96 nurses were included in the study because of personal reasons such as maternity leave or sick notes meaning that $95 \%$ of the population was reached.

In this research, a "Neonatal Patient Safety Questionnaire Form" consisting of two parts was prepared and used by the researchers in light of the existing literature $(8,14,15,16,17,18)$. The first part of the questionnaire was composed of 16 questions about the nurses' socio-demographic and professional characteristics and their views on patient safety. The second part was composed of 92 questions determining interventions of neonatal nurses regarding patient safety implementations. These questions were sent to 8 experts studying in the field of neonatal health care and their views were obtained. Kendall's W analysis was done in order to assess the compatibility of the experts' views. It was found that there was no statistical difference between the scores of 8 experts (Kendall's W=0.00, $p=0.67$ ) and that the experts' views were compatible with one another.

The questions that determined nursing interventions regarding patient safety in the second part were grouped under 7 headings: interventions regarding medication (20 questions), interventions regarding identity implementations (9 questions), interventions regarding care implementations (20 questions), interventions regarding hospital infections (16 questions), interventions regarding equipment use (11 questions), interventions regarding falling (6 questions) and interventions regarding communication (10 questions). The nurses were asked to reply to the questions related to interventions regarding patient safety implementations as "I implement", "I sometimes implement" and "I do not implement". For example, they were asked to choose from the options "I implement", "I sometimes implement" or "I do not implement" for the question "I tie the diaper folded below the umbilical cord." A scoring system was used to interpret interventions regarding patient safety practices in an easy way. Nurses' answers were scored as follows: "I implement" (3 points), "I sometimes implement" (2 points) and "I do not implement" (1 point). The scores obtained from the patient safety fields (field score) and from all items (total score) were calculated. Because the number of questions in the patient safety fields in our study were not the same, the data was converted to 0-100 score interval and each heading was formulized by being scored. The score calculation was as follows: [((Total score of the individual/ number of questions)-1)×50]. For example, the score of an individual whose total raw score from interventions regarding patient safety medication practices was 60 was calculated as follows: [((60/20)-1)×50=100].

The data was collected within two months by using a face-to-face interview method. The statistical analysis of the data was done by using number, percentage, KruskallWallis, Man-Whitney $U$ and Independent t tests. Permission to conduct the research was obtained from the ethics committee of Selcuk University, Faculty of Medicine Hospital. Verbal consent of the nurses working in NICU and written permissions from the related hospitals to conduct the research were obtained. 


\section{Findings}

\section{Descriptive Characteristics}

It was found that the age averages of the NICU nurses who participated in the study was $27.87 \pm 5.35$, that $41.7 \%$ of them were in the age group 24 to 29 and that $26.1 \%$ of them had one child. It was also determined that 55.2\% of the nurses were university graduates, that the average working years was $6.73 \pm 5.55$ and that the number of years working in NICU was $4.02 \pm 4.34$ years. $58.3 \%$ of the NICU nurses worked mixed shifts and cared for $6.58 \pm 2.41$ patients on average (Table 1). $40.6 \%$ of the nurses stated that they spend most of their working hours on nursing care, $13.5 \%$ stated that they spend most of their working hours on medical paperwork, $12.5 \%$ of them stated that they spend most of their working hours on diagnosis and therapy processions and $33.3 \%$ stated that they spend their working hours on all of these mentioned above.

\section{Information Regarding Patient Safety}

99\% of the NICU nurses stated that they were aware of patient safety and $51.6 \%$ stated that they have sufficient information on patient safety. $74 \%$ of the nurses stated that they have received training on patient safety, $62.5 \%$ stated that they have training on patient safety in the NICU they worked at and $81.2 \%$ stated that patient safety was of great importance (Table 2).

\section{Nurses' Intervention Scores Regarding Patient Safety Implementations}

Nurses' intervention scores regarding patient safety implementations in NICU (medication, identity, hospital infections, equipment use, falling, and communication) were determined in the research. Nurses' intervention scores regarding patient safety implementations were as follows: intervention score regarding medication implementations was 92.42 26.36 , intervention score regarding identity implementations was 63.14 \pm 30.30 , intervention score regarding care implementations was 91.69 \pm 8.59 , intervention score regarding hospital infections implementations was 95.41 \pm 6.80 , intervention score regarding equipment use was $87.83 \pm 13.68$, intervention score regarding falling was $95.75 \pm 7.35$, intervention score regarding communication was $92.19 \pm 11.74$ and the total score was $89.56 \pm 7.39$. It was seen that the nurses scored highest in interventions regarding falling (92.42 \pm 6.36 ) and scored lowest in interventions regarding identity implementations (63.14 \pm 30.30$)$.
Nurses' Intervention Scores Regarding Patient Safety Implementations and Related Factors

It was found that there was a meaningful difference in score averages of nursing intervention regarding medication implementations according to their level of education (Kendall's W=9.767, p=0.008). In further analysis (Bonferroni-corrected Mann Whitney $U$ test), it was revealed that score averages of university graduate nurses were meaningfully lower than high school graduate

Table I. Sociodemographic and professional characteristics of Neonatal Intensive Care Units nurse

\begin{tabular}{|c|c|c|}
\hline Variable & $\mathbf{n}$ & $\%$ \\
\hline \multicolumn{3}{|c|}{ Age groups (mean age: $27.87 \pm 5.35$ ) } \\
\hline $18-23$ & 20 & 20.8 \\
\hline $24-29$ & 40 & 41.7 \\
\hline 30 or over & 36 & 37.5 \\
\hline \multicolumn{3}{|c|}{ Number of children } \\
\hline none & 50 & 52.1 \\
\hline 1 child & 25 & 26.0 \\
\hline 2 or over & 21 & 21.9 \\
\hline \multicolumn{3}{|l|}{ Educational status } \\
\hline High school & 17 & 17.7 \\
\hline Associate degree & 26 & 27.1 \\
\hline University degree & 53 & 55.2 \\
\hline \multicolumn{3}{|c|}{ Number of years working in nursing (mean: $6.73 \pm 5.55$ ) } \\
\hline Less than one year & 5 & 5.2 \\
\hline $1-5$ years & 43 & 44.8 \\
\hline $6-10$ years & 25 & 26.0 \\
\hline more than 10 years & 23 & 24.0 \\
\hline
\end{tabular}

Number of years working with newborns (mean: $4.02 \pm 4.34$ )

\begin{tabular}{|l|l|l|}
\hline Less than one year & 12 & 12.5 \\
\hline 1-5 years & 59 & 61.5 \\
\hline 6-10 years & 15 & 15.6 \\
\hline more than 10 years & 10 & 10.4 \\
\hline \multicolumn{2}{|l|}{} \\
\hline Type of shifts & 19 & 19.8 \\
\hline Naytime & 21 & 21.9 \\
\hline Night and daytime mixed & 56 & 58.3 \\
\hline $\begin{array}{l}\text { The average daily number of patients receiving care } \\
\text { (mean = 6.58 } \pm \text { 2.41) }\end{array}$ & \multicolumn{2}{|l}{} \\
\hline 3-6 & 51 & 53.1 \\
\hline 7 or over & 45 & 46.9 \\
\hline
\end{tabular}


Table II. Neonatal Intensive Care Units nurses' opinions about patient safety

\begin{tabular}{|c|c|c|}
\hline Opinions & $\mathbf{n}$ & $\%$ \\
\hline \multicolumn{3}{|c|}{ Do you have information on the concept of patient safety? } \\
\hline Yes & 95 & 99.0 \\
\hline No & 1 & 1.0 \\
\hline \multicolumn{3}{|c|}{ If you answered yes to the above questions } \\
\hline I think it is sufficient & 49 & 51.6 \\
\hline I have a limited knowledge & 41 & 43.1 \\
\hline I think it is insufficient information & 5 & 5.3 \\
\hline \multicolumn{3}{|c|}{ Did you receive training on patient safety? } \\
\hline Yes & 71 & 74.0 \\
\hline No & 25 & 26.0 \\
\hline \multicolumn{3}{|c|}{ Is the unit where you work giving patient safety training? } \\
\hline Yes & 60 & 62.5 \\
\hline No & 36 & 37.5 \\
\hline \multicolumn{3}{|c|}{ Do you think patient safety matters? } \\
\hline Very important & 78 & 81.2 \\
\hline Important & 18 & 18.8 \\
\hline
\end{tabular}

nurses (Mann Whitney $U=812,500, p=0.004$ ). Also, there was a meaningful difference in nursing intervention score average regarding identity implementations in terms of working years (Kendall's W=9.259, $p=0.026$ ). In further analysis (Bonferroni-corrected Mann Whitney $U$ test), it was found that score averages of those nurses who had been working less than one year were meaningfully higher than those nurses who had worked 1 to 5 years (MW-U=28,500, $\mathrm{p}=0.005)$.

Also, it was determined in this study that nursing intervention score averages of those nurses who cared for 7 or more patients regarding identity implementations, equipment use and total patient safety score averages were meaningfully lower (respectively; $t=2.678, p=0.009$, $t=3.197, p=0.002, t=2.257, p=0.026$ ). It was also revealed that nursing intervention score averages regarding identity implementations of the nurses who received patient safety training were meaningfully higher compared to those nurses who did not receive training $(t=2.178, p=0.032)$ (Table 3$)$.

\section{Discussion}

This study aimed to determine the patient safety related implementations of nurses working in NICU and related factors. It was found that more than half of the NICU nurses provided care to 3-6 patients and less than half of them provided care to 7 or more patients. According to the circular issued by the Ministry of Health on the $3^{\text {rd }}$ of April 2008 03/04/2008, no.11395 (2008/25) one nurse in every shift in a Level 1 Intensive Care Unit is required whereas at least one nurse for 4 beds in every shift is required in a Level 2 Intensive Care Unit. Also, it was stated in the circular that in Level 3 Intensive Care Units, at least one nurse for three beds is required in each shift. It was seen in our study that the numbers of nurses per patient were low compared to the circular issued by the Ministry of Health. The fact that the number of nurses per patient is low creates problems such as fatigue, distraction, being unable to concentrate, and communication problems, heavy workload and burnout syndrome $(19,20)$. About half of the nurses participating in the study stated that they have spent most of their working hours on nursing care practices. In other studies, it was found that rather than focusing on patient care, nurses spent most of their time on supplying medicationequipment, answering the phone, writing out the suggested prescriptions or checking out entrance and exit times of employees. Moreover, they spent almost $1 / 3$ of their working time on indirect care practices $(18,21)$. In a study conducted by Turkmen and Uslu (17), it was stated that nurses spent $13.6 \%$ of their time which was allocated for the patient on indirect care implementations such as receiving and checking out doctor requests and that they spent $35.7 \%$ of their working hours on filling out forms. An inadequate number of nurses may result in allocating less time to patients, increased medical errors and reduced care duration and patient safety.

\section{Information Related to Patient Safety}

In this study, the nurses stated that they were aware of patient safety, received training on patient safety and patient care was of great importance. In another study, 95.2\% of nurses stated that patient safety is very important (22). In another study conducted by Pronovost et al. (7) in Britain, it was found that nurses' safety perception scores were higher than the doctors' safety perception scores. In a study done by Cirpi et al. (13), 96.9\% of the nurses stated that patient safety implementations were necessary, $93.3 \%$ of them stated that they were aware of patient safety implementations, and $92.3 \%$ of them stated that they volunteered to be assigned in patient safety implementations. From this aspect, our research findings bear similarities to the literature. It was seen in our study that nurses were aware of patient safety and valued the patient safety concept. Nurses play a key role in improving quality in health care. Establishing and improving patient safety could only be possible if the personnel 
Kaleci and Taş Arslan.

Patient Safety Proctices of Nurses

Table III. Neonatal intensive care units nurses for patient safety initiatives towards application ratings and comparison of related factors

Variable
$\begin{aligned} & \text { Educational status } \\ & \text { E }\end{aligned}$

Working in the profession for years

\begin{tabular}{|c|c|c|c|c|c|c|c|c|c|}
\hline $\begin{array}{l}\text { Less than one } \\
\text { year -a }\end{array}$ & 5 & $95.00 \pm 6.37$ & $94.44 \pm 9.62$ & $87.50 \pm 13.23$ & $96.25 \pm 6.77$ & $90.00 \pm 19.92$ & $96.67 \pm 4.56$ & $85.00 \pm 23.18$ & $91.96 \pm 11.21$ \\
\hline $1-5$ years -b & 43 & $91.98 \pm 6.67$ & $56.33 \pm 29.98$ & $91.80 \pm 8.15$ & $94.69 \pm 7.70$ & $84.04 \pm 15.02$ & $95.16 \pm 8.77$ & $92.56 \pm 11.92$ & $88.25 \pm 7.67$ \\
\hline 6-10 years & 25 & $92.10 \pm 6.44$ & $70.22 \pm 28.14$ & $93.60 \pm 7.64$ & $96.00 \pm 5.67$ & $92.36 \pm 7.03$ & $96.00 \pm 6.42$ & $92.20 \pm 11.55$ & $91.26 \pm 6.42$ \\
\hline $\begin{array}{l}\text { more than } 10 \\
\text { years }\end{array}$ & 23 & $93.04 \pm 5.89$ & $61.35 \pm 31.53$ & $90.33 \pm 9.27$ & $95.92 \pm 6.42$ & $89.53 \pm 14.01$ & $96.38 \pm 6.06$ & $93.04 \pm 8.22$ & $89.65 \pm 6.91$ \\
\hline KW (SD: 3) & - & 1.304 & 9.259 & 2.539 & 0.478 & 6.611 & 0.047 & 0.635 & 4.048 \\
\hline p & - & 0.728 & 0.026 & 0.468 & 0.924 & 0.085 & 0.997 & 0.888 & 0.256 \\
\hline Difference & - & - & $\mathbf{a}>\mathbf{b}$ & - & - & - & - & - & - \\
\hline \multicolumn{10}{|c|}{ Newborn working years } \\
\hline $\begin{array}{l}\text { Less than one } \\
\text { year }\end{array}$ & 12 & $93.96 \pm 7.27$ & $78.24 \pm 31.02$ & $94.38 \pm 10.12$ & $97.40 \pm 4.58$ & $88.26 \pm 17.60$ & $95.83 \pm 7.54$ & $91.25 \pm 16.53$ & $92.26 \pm 9.22$ \\
\hline $1-5$ years & 59 & $92.58 \pm 6.69$ & $62.05 \pm 30.52$ & $91.78 \pm 7.97$ & $94.65 \pm 7.43$ & $86.67 \pm 12.80$ & $95.62 \pm 7.94$ & $92.54 \pm 11.68$ & $89.27 \pm 7.44$ \\
\hline 6-10 years & 15 & $90.83 \pm 4.60$ & $53.70 \pm 22.09$ & $89.83 \pm 11.20$ & $97.71 \pm 3.44$ & $92.42 \pm 10.12$ & $96.11 \pm 5.33$ & $92.00 \pm 9.41$ & $88.84 \pm 6.22$ \\
\hline $\begin{array}{l}\text { more than } 10 \\
\text { years }\end{array}$ & 10 & $92.00 \pm 5.75$ & $65.56 \pm 35.89$ & $90.75 \pm 5.66$ & $94.06 \pm 8.26$ & $87.27 \pm 18.41$ & $95.83 \pm 7.08$ & $91.50 \pm 10.01$ & $89.13 \pm 6.72$ \\
\hline KW (SD: 3) & - & 3.166 & 4.496 & 3.927 & 2.246 & 3.924 & 0.234 & 0.697 & 4.518 \\
\hline p & - & 0.367 & 0.213 & 0.269 & 0.523 & 0.270 & 0.972 & 0.874 & 0.211 \\
\hline
\end{tabular}

Shape shifts

\begin{tabular}{|l|l|l|l|l|l|l|l|l|l|}
\hline Daytime & 19 & $93.68 \pm 4.89$ & $54.68 \pm 27.67$ & $91.32 \pm 7.61$ & $94.41 \pm 6.21$ & $89.71 \pm 12.29$ & $95.61 \pm 6.44$ & $92.37 \pm 8.39$ & $88.99 \pm 4.75$ \\
\hline Night & 21 & $91.43 \pm 6.15$ & $69.84 \pm 32.09$ & $91.79 \pm 9.05$ & $94.05 \pm 8.14$ & $89.18 \pm 10.99$ & $95.24 \pm 8.96$ & $90.71 \pm 16.30$ & $89.75 \pm 8.71$ \\
\hline $\begin{array}{l}\text { Night and } \\
\text { daytime } \\
\text { mixed }\end{array}$ & 56 & $92.37 \pm 6.89$ & $63.49 \pm 30.32$ & $91.79 \pm 8.86$ & $96.26 \pm 6.43$ & $86.69 \pm 15.06$ & $95.98 \pm 7.11$ & $92.68 \pm 10.83$ & $89.68 \pm 7.70$ \\
\hline KW (SD: 2) & - & 0.999 & 2.861 & 0.307 & 2.716 & 0.402 & 0.253 & 0.433 & 1.492 \\
\hline p & - & 0.607 & 0.239 & 0.858 & 0.257 & 0.818 & 0.881 & 0.805 & 0.474 \\
\hline
\end{tabular}

The average daily number of patients receiving care

\begin{tabular}{|l|l|l|l|l|l|l|l|l|l|}
\hline 3-6 & 51 & $92.45 \pm 6.25$ & $72.00 \pm 27.87$ & $93.38 \pm 8.50$ & $96.08 \pm 6.43$ & $90.73 \pm 12.50$ & $96.57 \pm 7.30$ & $92.94 \pm 10.87$ & $91.40 \pm 6.95$ \\
\hline 7 or over & 45 & $92.39 \pm 6.55$ & $53.09 \pm 30.09$ & $89.78 \pm 8.37$ & $94.65 \pm 7.19$ & $84.55 \pm 14.35$ & $94.81 \pm 7.39$ & $91.33 \pm 12.72$ & $87.48 \pm 7.40$ \\
\hline t (SD: 94) & - & 0.047 & 3.197 & 2.088 & 1.025 & 2.257 & 1.168 & 0.668 & 2.678 \\
\hline p & - & 0.962 & 0.002 & 0.039 & 0.308 & 0.026 & 0.246 & 0.506 & 0.009 \\
\hline
\end{tabular}

Patient safety training receive status

\begin{tabular}{|l|l|l|l|l|l|l|l|l|l|}
\hline Yes & 75 & $92.82 \pm 6.34$ & $67.06 \pm 28.07$ & $91.16 \pm 8.83$ & $95.25 \pm 7.28$ & $89.44 \pm 11.67$ & $95.66 \pm 7.43$ & $91.90 \pm 12.20$ & $90.04 \pm 7.44$ \\
\hline No & 21 & $91.30 \pm 6.42$ & $52.00 \pm 34.09$ & $93.20 \pm 7.82$ & $95.88 \pm 5.32$ & $83.27 \pm 17.74$ & $96.00 \pm 7.26$ & $93.00 \pm 10.51$ & $88.20 \pm 7.24$ \\
\hline $\mathbf{t}$ (SD: 94) & - & 1.026 & 2.178 & 1.021 & 0.396 & 1.966 & 0.199 & 0.401 & 1.074 \\
\hline p & - & 0.308 & 0.032 & 0.310 & 0.693 & 0.052 & 0.842 & 0.690 & 0.285 \\
\hline KW: Kendall's W, SD: Standard deviation \\
\hline
\end{tabular}


comprehended the importance of the issue. In this context, training the health personnel in a hospital may develop an understanding regarding patient safety.

\section{Intervention Scores of Nurses Regarding Patient Safety Implementations}

In this research, nurses scored highest in implementations regarding falling followed by hospital infections, medication, communication, care, and equipment use respectively and scored lowest in identity practices. These implementations might affect neonatal care, morbidity and mortality. In the literature, it was stated that medication errors are most common among the issues affecting patient safety $(5,23,24)$. This might be related to the abundant number of studies on medication implementations. The fact that identity implementation scores were lowest show that these are not implemented precisely. Identifying the patient and performing related nursing interventions in NICU and other clinics is vital. With this in mind, creating procedures regarding identity implementations, training and inspecting these implementations are needed.

\section{Factors Related to Intervention Scores Regarding Patient Safety Implementations}

It was found in this study that score averages of high school graduate nurses were higher than the score averages of university graduate nurses in terms of medication implementations. This is thought to have resulted from the fact that the sample group was small. It was also found in this research that score averages in terms of identity implications of nurses who had worked less than one year were higher than those nurses who had worked between 1 and 5 years. This result might show that nurses who had worked less than one year were novice nurses and were careful not to make any mistakes. It was found that in patient safety intervention score averages of identity implementations and equipment use by the number of patients who were provided daily care and in total patient safety scores, the score averages of those nurses who provided care for 7 or more patients were lower than those nurses who provided care for between 3 and 6 patients. These results show that the number of patients per nurse affects patient safety in $\mathrm{NICU}$. As the number of patients per nurse increases, the risk of therapy and care errors increase. It is accepted that patients are safest when one nurse is assigned to one or two patients in intensive care units (25).

In this research, it was determined that nurses who received training scored higher than those nurses who did not by receiving training in patient safety in terms of identity implementations. Nursing interventions regarding identity implementations are implemented the least, but it is thought that providing training in all patient safety fields would increase the level of information. It was also concluded that providing these trainings at regular intervals would improve patient safety and increase care standards.

\section{Limitations of Research}

The limitation of this study is that it only sampled nurses working in hospitals with NICU in Konya province.

\section{Conclusion}

Patient safety in neonatal units is one of the basic factors in nursing care. Providing care for human beings without causing any harm is the foundation of the nursing profession. Nurses who work in units such as NICU where sensitivity is required in patient safety have to play a lot of roles in this issue.

In this research, it was seen that nurses were aware of patient safety and performed related implementations. The nurses scored highest in interventions regarding falling and scored lowest in interventions regarding identity implementations. It was also revealed that the nurses' patient safety implementations were related to their level of education, years of working, the number of patients who were provided with care daily, and receiving training on patient safety.

It is suggested that nurses, who play a key role in providing patient safety, should improve patient safety implementations. With this aim in mind, NICU- unique guidelines should be prepared in patient safety fields (medication, identity, providing care, hospital infections, equipment use, falling and communication). In activities such as in-service training, congresses, seminars, conferences or symposiums etc. patient safety should be included more extensively and these programs should be repeated at regular intervals. The number of nurses and patients to be provided with daily care should accord with the standards and their continuity should be ensured to increase success in patient safety implementations. In order to prevent medical errors, patient safety culture should be created in hospitals and an active error notification system should be set up. Committees related to patient safety should be established in health institutions and they should work actively.

\section{Ethics}

Ethics Committee Approval: The study was approved by the Selçuk University Faculty of Medicine Ethics Committee (Approval number: 2012/04, 24.04.2012). 
Informed Consent: Consent form was filled out by all participants.

Peer-review: Externally peer-reviewed.

\section{Authorship Contributions}

Concept: E.K., F.T.A., Design: E.K., F.T.A., Data Collection or Processing: E.K., Analysis or Interpretation: E.K., F.T.A., Literature Search: E.K., Writing: E.K., F.T.A.

Conflict of Interest: No conflict of interest was declared by the authors.

Financial Disclosure: This research was financially supported both via oral presentation and the thesis by the Selçuk University Scientific Research Projects Coordinatorship in Konya, Turkey.

\section{References}

1. Aydın B. Ülkemizde hasta güvenliği. Sağlık Yönetimi ve Eğitimi Dergisi 2009; 2:17-19.

2. Hemmat F, Atashzadeh-Shoorideh F, Mehrabi T, Zayeri F. A survey of nurses' awareness of patient safety culture in neonatal intensive care units. Iranian journal of nursing and midwifery research 2015, 20: 490-495.

3. Abu-El-Noor NI, Hamdan MA, Abu-El-Noor MK, Radwan AKS, Alshaer AA. Safety Culture in Neonatal Intensive Care Units in the Gaza Strip, Palestine: A Need for Policy Change. Journal of pediatric nursing 2017; 33:76-82.

4. Donchin $Y$, Gopher D, Olin M, Badihi Y, Biesky M, Sprung CL, Pizov R, Cotev S. A look into the natüre and causes of human errors in the intensive care unit. Qual Saf Health Care 2003, 12: 143-147.

5. Durmaz A, Mete S. Hastalarin Hastaneye Yatmadan Önce Kullandıklari ilaçlara iliş̧kin Hemşire Notlarındaki ilaç Kayıt Hatalarının İncelenmesi. C.Ü. Hemşirelik Yüksekokulu Dergisi 2007, 11: 1-7.

6. Ergenekon E. Yenidoğan yoğun bakım ünitesi tasarımı. T Klin J Pediatr 2001, 10: 1-5.

7. Pronovost PJ, Thompson DA, Holzmueller CG, Lubomski LH, Morlock LL. Defining and measuring patient safety. Critical Care Clinics 2005, 21: 1-19.

8. Yıldız S. Yenidoğan yoğun bakım ünitelerinin organizasyonu, Temel Neonatoloji ve Hemşirelik ilkeleri, Yenilenmiş 2. Baskı, istanbul, Nobel Matbaacılık, 2008.

9. Savaşer S, Çimen S, Yıldız S. Flakon şeklindeki antibiyotiklerde kuru toz hacminin uygulanacak doz üzerine etkisi. İstanbul Üniversitesi Florence Nightingale Hemşirelik Yüksekokulu Dergisi 2008, 16: 7-15.

10. Van Geest IB, Cummins DS. An educational needs assessment for improving patient safety. National Patient Safety Foundation, White paper report, 2003.
11. Samra HA, Jacqueline MM, Rollins W. Patient safety in the NICU: Acomprehensive review. The Journal of Perinatal and Neonatal Nursing 2011, 25: 123-132.

12. Başbakkal Z, Taş F, Yılmaz HB. Pediatri kliniklerinde çalışan hemşirelerin hasta güvenliği kültürüne ilişkin görüşlerinin incelenmesi. Ege Pediatri Bülteni 2009, 16: 87-93.

13. Çırpı F, Merih DY, Kocabey MY. Hasta güvenliğine yönelik hemşirelik uygulamalarının ve hemşirelerin bu konudaki görüşlerinin belirlenmesi. Maltepe Üniversitesi Hemşirelik Bilim ve Sanatı Dergisi 2009, 3:26-34.

14. Resmi Gazete. 27897 sayılı Hasta Ve Çalışan Güvenliğinin Sağlanmasına Dair Yönetmelik, 2011.

15. Sayek F. Hasta Güvenliği: Türkiye Ve Dünya Türk Tabipleri Birliği(TTB) Raporları, Birinci Baskı, Ankara, Türk Tabipleri Birliği Yayınları, 2011.

16. T.C. Sağlık Bakanlığı Refik Saydam Hıfzıssıhha Merkezi Başkanlığı. Ulusal hastane enfeksiyonları sürveyansı Centers for Disease Control and Prevention (CDC) tarafından belirlenen hastane enfeksiyonu tanımları, 2010.

17. Türkmen E, Uslu A. Özel bir hastanede hemşirelerin dolaylı bakım uygulamalarının değerlendirilmesi. İstanbul Üniversitesi Florence Nightingale Hemşirelik Yüksekokulu Dergisi 2011, 19: 60-67.

18. Yıldırım Ö. Sağlık kuruluşlarında hasta güvenliğinin önemi, yaklaşımları ve insan faktörü mühendisliğinin hasta güvenliği ile ilişkisi, 1. Baskı, İstanbul, Beta Basın Yayım, 2012.

19. Özkan S, Kocaman G, Öztürk C. Interruptions during pediatric medication preparation and administration. The Journal of Pediatric Research 2016, 3: 104-8.

20. T.C. Sağlık Bakanlığı Sağlık Eğitimi Genel Müdürlüğü. 9532 sayılı Lisans Tamamlama Programı Konulu Genelge, 2009.

21. Türk Tabipler Birliği(TTB) Yenidoğan yoğun bakım birimlerinde bebek ölümleriyle ilgili komisyon raporu. 2005; http://www. ttb.org.tr/kutuphane/bebek_olumleri.pdf / Erişim Tarihi 5 Nisan 2018.

22. Yıldırım D. Hemşirelerin servislerde hastalarla ve diğer işlere ayırdıkları sürelerin değerlendirilmesi. İstanbul Üniversitesi Florence Nightingale Hemşirelik Yüksekokulu Dergisi 2006, 4: 177-192.

23. Institute Of Medicine (IOM). To Err is Human: Building A Safer Health System, Washington DC, National Academies Press, 1999.

24. T.C. Sağlık Bakanlığı Tedavi Hizmetleri Genel Müdürlüğü. 11395 sayılı Yoğun Bakım Ünitelerinin Standartları Konulu Genelge, 2008.

25. Karabıyık L. Yoğun bakımda sık yapılan tıbbi hatalar. Yoğun Bakım Dergisi 2012, 10: 40-49. 